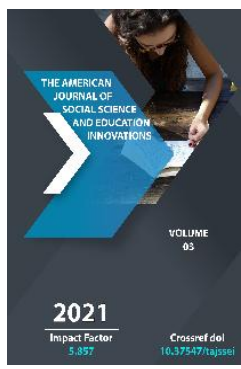

\title{
Age Determination Of Buddhist Cult Complexes Of Northwestern Bactria-Tokharistan
}

\author{
Jaloliddin Annaev \\ Department Of Archaeology, National University Of Uzbekistan, Tashkent, Uzbekistan
}

\begin{abstract}
Journal Website:
http://theamericanjour

nals.com/index.php/taj ssei

Copyright: Original content from this work may be used under the terms of the creative commons attributes 4.0 licence.
\end{abstract}

\section{ABSTRACT}

In the Twenty-First Century, in the context of globalization processes, special attention is paid to the study of the contribution of religions to the development of world civilization, spirituality and enlightenment, because spiritual culture determined the progress of society and, since ancient periods, has been closely associated with religious views and beliefs. This definition is fully applying to Buddhism, that existed for many centuries in the south of Central Asia, including in the historical and cultural region of Bactria, along with Zoroastrianism and other religions.

Central Asia is considered as a territory of distribution of various religious views, religions and teachings by the world's leading research institutions since ancient times. In this regard, special studies have been conducted and their results were published in many scientific publications. In particular, Uzbek and foreign scientists carried out fundamentally important archaeological work with the aim of studying the Buddhist monuments of Tarmidh-Termez, as well as identifying the features of the spread of Buddhism through this region to Margiana, Sogdiana and East Turkistan. From this point of view and out of the need to analyze other topical issues (spiritual and material culture, fine arts, numismatics and epigraphy, reconstruction of the functions of Buddhist centers), additional research based on new approaches is an urgent scientific task.

\section{KEYWORDS}

Central Asia, Buddhism, Margiana, Sogd, East Turkistan, Buddhist centers, Bactria-Tokharistan, Ancient Termez, Tarmidh-Termez, Karatepa, Fayaztepa, Ushtur mullo, Chingiztepa. 


\section{INTRODUCTION}

The initial information about the Buddhist monuments of Ancient Termez is given in the publications of A.A. Stael-Holstein [58, PP. 922; 2, PP. 1-8] and V.V. Bartold [22, P. 469] that were based on summarizing Hiuen Tsiang 's information [10, P. 38].

Expedition of the Museum of Oriental Cultures (Moscow), led by B.P. Denyke, conducted scientific research at the monuments of Zurmala and Karatepa of Ancient Termez in 1926-1928. Expedition member A.S. Strelkov investigated the Zurmala monument [59, PP. 27-30; 60, PP. 216-224] and discovered cave buildings on Karatepa [57, PP. 70-76]. In 1934, Karatepa was studied by G.V. Parfenov [57, PP. 70-76; 30, PP. 83-84; 34, PP. 83-84], and in 1936-1939, archaeological research on Karatepa and Chingiztepa was carried out by the staff of TACE (A.A.Strelkov, V.A.Shishkin, BB Piotrovsky, E.G. Pchelina) under the leadership of M.E. Masson [61, - 215 p; 62, 226 p.].

This period is characterized by the starting of the investigating of archaeological materials, as well as the history of the material culture of the Buddhist monuments of Ancient Termez.

During $60 \mathrm{~s}$ and $80 \mathrm{~s}$ of the 20th centuries, a joint expedition (the Department of the East of the State Hermitage and the Museum of Oriental Art) led by B.Ya. Stavisky studied the lay out structure of buildings that were discovered in the southern and partly in the northern hills of the cult center of Karatepa, where important scientific materials on Buddhist architecture, art, epigraphy and material culture were obtained. The results of archaeological research were published in 6 collections [34, - 111 p; 26, - 185 p; 27, - 177 p; 25, - $199 \mathrm{p} ; 24,-341 \mathrm{p}$.$] .$
Along with the identification of the architectural-planning structure and stages of the functioning of Karatepa, data on its chronology have been introduced into scientific circulation.

In 1964-1965, G.A. Pugachenkova and Z.A. Khakimov continued their studies of the Zurmala stupa, as a result of which the reconstruction of the monument was proposed in the form of a 16-meter-high monumental structure, with a hemispherical dome [53, PP. 257-263]. In 1968-1976, L.I. Albaum and V.A. Kozlovsky carried out extensive archaeological excavations in Fayaztepa, which made it possible to reveal a monumental Buddhist monastery, study Buddhist culture, architecture, fine arts, writing, rare archaeological finds and obtain important scientific data [17, P. 54].

In the 1990s and early 2000s, Buddhist art, material culture, architecture, coin findings, samples of ancient Indian, Bactrian and "unknown" writing of Northern Bactria, including Tarmidh-Termez, as well as the spreading of Buddhist teachings to the territory of Central Asia, were reflected in the studies of G.A. Pugachenkova [8, PP. 23-41; 31, 342 p.], B.Ya. Stavisky [11, PP. 219-232; 56, PP. 209 p.], L.I. Albaum [16, PP. 18-28], E.V. Rtveladze [54, PP. 72-77], B.A. Litvinsky [35, PP. 188-199], V.V. Vertogradova [28, PP. 2833], T. K. Mkrtychev [36, PP. 27-56; 37, 286 p.], K. Abdullaev [1, PP. 157-189], Sh. Pidaev [44, PP. 11-27; 42. PP. 38-43; 40, PP. 33-42; 39, PP. 82-83; 41, 117 P; 7. 95 P.], G. Fussman [6. PP. 3280], T. Annaev [18, PP. 53-66], M. Bolganova [23, 40 p.], V.S. Solovyev [55, 129 p.], R. Salomon [28, PP. 139-170], A. Iwamoto [3, PP. 151-178].

As a result of new research in the years of independence, the Uzbek-Japanese 
expedition to Karatepa revealed the location of monastery in the northern part of this monument and obtained important scientific data on the history of Buddhism in TarmidhTermez [47, PP. 82-84; 48, 56 p; 45, PP. 114122; 46, PP. 147-158].

A joint expedition of the Institute of Art Studies of the Academy of Sciences of the Republic of Uzbekistan and the National Research Institute of Cultural Heritage of the Republic of Korea revealed buildings similar to what had been excavated earlier in the same part of the complex on the southern hill of the Buddhist center Karatepa [12, 219 p.].

As a result of work with archaeologists of the Japanese University of Rissho, the bypass corridor and the premises connected to it were studied in the southwestern part of the central stupa [4, 242 p.].

In the complex of the Karatepa monastery, the Termez archaeological expedition led by Sh. Pidaev revealed samples of wall painting, which is an important source for restoring the appearance, clothing and jewelry of the Bactrians [43, PP. 45-48]. As part of an international project, research was carried out with the aim of reconstructing and preserving the Zurmala stupa [13, $10 \mathrm{p}$.$] .$

The Uzbek-French Bactrian expedition excavated a Buddhist stupa [5, PP. 179-211. fig.8.; and cave cells [39, PP. 82-83] in the southwestern corner of Ancient Termez. As a result of these studies, new materials were obtained on the history of the culture of Buddhism.

An archaeological team led by T. Annaev, with the direct participation of the author of this article, excavated more than a dozen Buddhist cave constructions near the mausoleum of Muhammad Hakim Tirmidhi [64, PP. 67-78] and two Buddhist temples in the Chingiztepa complex [50, PP. 105-114; 49, PP. 134-143; 20, PP. 63-67].

Within the framework of the international project "Reconstruction and preservation of the ruins of Fayaztepa" under the leadership of Sh. Pidaev, additional studies of Fayaztepa's stupa and the adjacent territory were carried out, as a result of which the period of the construction of the stupa and the monastery part was clarified [40, PP. 3342].

New excavations at Fayaztepa were also carried out by an archaeological team led by $T$. Annaev, with the participation of the author of this article [18, PP. 53-66].

\section{Stages of the formation of Buddhist centers in Northwestern Bactria and their periodization}

According to the results of the archeological investigations, it has been established that Tarmidh-Termez was the early center of penetration and spreading of Buddhist teachings in the north part of the Oxus-Amu Darya.

At the beginning of the 1st century $A D, a$ monumental Buddhist monastery was erected on the site of an early Buddhist building on Fayaztepa [18, PP. 53-66].

According to the stratigraphy of ancient Indian inscriptions, Karatepa is dated to the first half of the 1st century AD. According to Sh. Pidaev, in the second half of the 1st century $A D$, a ground Buddhist structure was erected on the northern hill of the future cult center and that was the second Buddhist complex of Tarmidh-Termez of the Kushan period [41, 117 p.].

In Tarmidh-Termez, during the period of the great Kushans, along with the transformation 
of the Buddhist cult center Karatepa into "Khadevaka vihara", three more Buddhist complexes were founded. The first of them is a large Buddhist stupa, known as the Zurmala Tower. The second complex of structures was located to the north of the rabad part of medieval Termez, from which an underground room has been preserved [29, PP. 118-119]. The third complex of Buddhist buildings is Chingiztepa [6, PP. 3-280].

At the beginning of the early Middle Ages, with a gradual decrease of the role of the Buddhist cult complexes Karatepa and Fayaztepa, a new Buddhist monastery of the 4th-5th centuries $A D$ was erected on the site of the mausoleum of Muhammad Khakim Tirmidhi, as well as in the northern and eastern parts of it and on the site of Dunyotepa [19, PP. 15-18].

Based on the age determination of the Buddhist monuments of the Surkhan Oasis and the analysis of the chronological data of individual Buddhist findings three main directions of the spreading of Buddhism from Tarmidh-Termez to other regions of Northern Bactria were identified.

The first direction is the right bank of the upper reaches of the Amu Darya. In chronological terms, after the Buddhist complexes of Fayaztepa and Karatepa, Buddhist structures were built in Ayrtam [54, PP. 72-77] and, possibly, in Ushtur-mullo as well [32, PP. 70-86].

The second way of spreading Buddhism from Tarmidh-Termez passed through the basin of the upper reaches of the Surkhandarya. In this direction, Buddhist monuments have been discovered at the Dalvarzintepa settlement [52, P. 197; 51, PP. 90-97; 33, PP. 26-28, 63, PP. 81-95], and in other ancient settlements, individual findings related to Buddhism have been recorded.
The third path of the spread of Buddhism from Tarmidh-Termez led towards the "Iron Gates". Buddhist religious buildings were found within a radius of $30 \mathrm{~km}$ from Ancient Termez, and samples of Buddhist art within a radius of up to $70 \mathrm{~km}$. Further to the north, no artifacts of Buddhist art have been found on the monuments located in the "Iron Gate" area, Payankurgan and others (mainly fortress-type structures) [21, 40 p; 14, PP. 1830; 15, PP. 25-30].

\section{CONCLUSION}

New archaeological discoveries made it possible to determine that the Buddhist teaching in Northwestern Bactria originally spread in Tarmidh-Termez from Kabul-Balkh and the main ways of spreading Buddhist teachings from Tarmidh-Termez to Northern Bactria were identified.

Fayaztepa was one of the early Buddhist centers of Tarmidh-Termez. In the early Middle Ages, with a gradual decrease of the role of the cult complexes of Karatepa and Fayaztepa, other Buddhist monasteries were formed (on the site of the mausoleum of Muhammad Hakim Tirmidhi, in the territory to the north and east of it and on Dunyotepa).

According to the archaeological results in Tarmidh-Termez, as well as in Bamiyan and East Turkestan, there was a development of the traditions of Buddhist underground architecture.

The layout structure of Buddhist monuments, the analysis of epigraphical findings and the activities of Buddhist preachers indicate that Tarmidh-Termez served as a kind of "bridge" for the spreading of Buddhist teachings in Central Asia and the Far East.

REFERENCES 
1. Abdullaev K. The Buddhist culture of Ancient Termez in old and recent finds // Parthica. Incontri di culture nel mondo Antico. - PisaRoma. Fabrizio Serra editore, 2013. - Pp. 157-189.

2. Elisseeff Serge. "Stael-Holstein's Contribution to Asiatic Studies." Harvard Journal of Asiatic Studies. Vol. 3, No. 1. Harvard-Yenching Institute, 1938. - Pp. 1-8.

3. Iwamoto A. A Study on the Prosperity and Decline of Buddhist Sites in Northern Bactria: Kara Tepe and Zurmala // The Rissho international journal of academic research in culture and society. Tokyo: 2019. - Pp. 151- 178.

4. Kara Tepe - Buddhist Complex Of Termez 2014-2017. - Osaka: Shobo, 2020. -242 p.

5. Leriche P., Pidaev Sh. Termez in Antiquity. After Alexander: Central Asia before Islam // Proceeding of the British Academy. Oxford University, - London. 2007. - Pp. 179-211. fig.8.

6. Pidaev Sh, Annaev T et Fussman G. Monuments Bouddhiques de Termez. - Paris: College de France. Publications de L'Institut de civilazion indienne. Diffusion de Boccard. Fascule 79,2. 2011. - Pp. 3-280.

7. Pidaev Sh., Kyuzo K., Eiichi I. Buddhist cultural heritage. Osaka: Shobo, 2019. - 95 p.

8. Pugachenkova G.A. The Buddhist monuments of Airtam // Silk Road art and archaeology. Vol. 2. Kamakura-shi, - Japan. 1991/ 92. Pp. 23-41.

9. Scherrer-Schaub C., Salomon R., Baums S. Buddhist Inscriptions from Termez (Uzbekistan): A New Comprehensive Edition and Study /I Indo-Iranian Journal. Vol.55. USA. 2012. - Pp. 139-170.

10. Si-Vu-Ki: Buddhist records of the Western world, translated by from Chinese of Hiuen Tsiang (A.D. 629) by Samuel Beal. Vol. I. - London. Trübner \& Co., Ludgate hill, 1884. - P. 38 .

11. Staviskii B., Mkrtychev T. QaraTepe in Old Termez: On the History of the Monument // Bulletin of the Asia Institute, Vol. 10. 1996. - Pp. 219-232.

12. Uzbekistan. Kushan Dynasty and Buddhism. - Seoul: National Research Institute of Cultural Heritage, 2013. - 219 p.

13. Zurmala: A Stupa in Termez // Basic Research Report. - Tokyo: Rissho University, 2017. - 10 p.

14. Абдуллаев К. K атрибуции тронных изображений в кушанской коропластике (по материалам крепости Паенкургана в Северной Бактрии) // ВДИ. - М., 2000. №2, C.18-30. (In Russian).

15. Абдуллаев К. Раскопки на Паенкургане в Байсунском районе (северная Бактрия) // Археологические исследования в Узбекистане -2000 год. Самарканд. 2001. - С. 25-30. (In Russian).

16. Альбаум Л.И. Живопись святилища Фаязтепа // Культура Среднего Востока (с древнейших времен до наших дней). Изобразительное и прикладное искусство. - Ташкент: Фан, 1990. - C. 18-28. (In Russian). 
17. Альбаум Л.И. Раскопки буддийского комплекса Фаязтепа (по материалам 19681972 гг.) // Древняя Бактрия. - Л., Наука, 1974. - С. 54. (In Russian).

18. Аннаев Дж., Аннаев Т. Архитектурно-планировочная структура и датировка буддийского монастыря Фаязтепа // Традиции Востока и Запада в античной культуре Средней Азии. - Ташкент: Ноширлик ёғдуси, 2010. - С. 5366. (In Russian).

19. Аннаев Ж. Пещерные сооружения у мавзолея ал Хаким ат-Термизий// Материалы Международной научной конференции «Актуальные проблемы механики и горного машиноведения, развития науки и интеграции ВУЗов». Международный нучный журнал. Наука, образование, техника, №2 (30), часть 2. - Ош, 2009. - C.1518. (In Russian).

20. Аннаев Т., Лериш П., С. Де Понбрианд, Аннаев Дж., Холиков 3., Худаёбердиев Ш. Археологические работы на крепости Чингизтепа и Чингиз-2 городища Старого Термеза // Археологические исследования в Узбекистане-2013-2014 гг. Самарканд. 2016. Вып.10. - С.6367. (In Russian).

21. Аннаев Т., Тиловов Б., Худойбердиев Ш. Бойсун археологик ёдгорликлари. Тошкент: А. Қодирий номидаги халқ мероси нашриёти, 1999. 40 б. (In Uzbek).

22. Бартольд В.В. Работы по исторической географии и истории Ирана / Сочинения. Том VII. - М.: Наука, 1971. - С. 469. (In Russian).

23. Болганова М.С. Архитектура буддийских памятников Средней Азии: Автореф. дис. канд. арх. наук. - Ташкент: ТАСИ, 2011. - 40 c. (In Russian).

24. Буддийские комплексы Каратепе в Старом Термезе. - М.: ИВЛ, 1996. - 341 с. (In Russian).

25. Буддийские памятники Кара-тепе в Старом Термезе. - М.: Наука, 1982. - 199 c. (In Russian).

26. Буддийские пещеры Кара-тепе в Старом Термезе. - М.: Наука, 1969. - 185 с. (In Russian).

27. Буддийский культовый центр Кара-тепе в Старом Термезе. М.: Наука, 1972. - 177 с. (In Russian).

28. Вертоградова В.В. Индийская эпиграфика из Кара-тепе в Старом Термезе. Проблемы дешифровки и интерпретации. М.: ИВЛ, 1995. - С. 28-33. (In Russian).

29. Воробьева-Десятовская М.И. Новые надписи с письмом кхароштхи из Термеза // ВДИ. M., 1974. №1, - C. 118-119. (In Russian).

30. Грек Т.В., Пчелина Е.Г., Ставиский Б.я. Кара-тепе-буддийский пещерный монастырь в Старом Термезе. - М.: Наука, 1964. - С. 83-84. (In Russian).

31. Древности Южного Узбекистана / Отв. ред. Г.А. Пугаченкова. Токио, 1991. - 342 с. (In Russian).

32. Зеймаль Т.И. Буддийская ступа у Верблюжьей горки (к типологии ступ правобережного Тохаристана) // Прошлое 
Средней Азии. - Душанбе, Дониш, 1987, - С. 70-86. (In Russian).

33. Ильясов Дж. $\mathrm{k}$ вопросу о датировке буддийских храмов на Далварзинтепа // Археология и художественная культура Центральной Азии. - Ташкент: 1995. - C. 26-28. (In Russian).

34. Кара-тепе-буддийский пещерный монастырь в Старом Термезе. - М.: Наука, 1964. - 111 с. (In Russian).

35. Литвинский Б.А. Буддизм в Средней Азии // ВДИ. - М., 2001. №4. - C. 188-199. (In Russian).

36. Мкртычев Т.К. Буддизм в Термезе // Термез древний и новый город на перекрестке великих дорог. -Ташкент: Шарк, 2001. - C. 27-56. (In Russian).

37. Мкртычев Т.К. Буддийское искусство Средней Азии. - М.: ИКЦ «Академкнига», 2002. - 286 c. (In Russian).

38. Новые находки Кара-тепе в Старом Термезе. - М.: Наука, 1975. - 175 c. (In Russian).

39. Пидаев Ш. Р., Баратова Л.С. Новые данные к истории средневекового Термеза // Древние цивилизации на Среднем Востоке. Археология, история, культура. Материалы международной научной конференции. - М.: Наука, 2010. C. 82-83. (In Russian).

40. Пидаев Ш.Р. Исследование ступы Фаязтепа // Консервация и реставрация руин Фаязтепа. Обобщающий отчет. - Ташкент: 2006. - C. 33-42. (In Russian).

41. Пидаев Ш.Р. Қадимги Ўзбекистонда буддавийлик ва буддавий мерос. - Тошкент: O'zbekiston, 2011. - 117 6. (In Uzbek).

42. Пидаев Ш.Р. Қоратепа Ўзбекистондаги буддавийлик маркази // Мозийдан садо, 2004. 1(21). - Б. 38-43. (In Uzbek).

43. Пидаев Ш.Р. Қоратепадаги будда ибодатхонасининг деворий суратлари // Фан ва Турмуш. 2016. №3-4. - Б. 45-48. (In Uzbek).

44. Пидаев Ш.Р. Тармита-Термез 1220 йилгача: шахарнинг вужудга келиши ва тадрижий ривожланиши // Термез буюк йуллар чоррахасидаги кўхна ва янги шахар. - Тошкент: Шарқ, 2001. - Б. 11-27. (In Uzbek).

45. Пидаев Ш.Р., Кюдзо К. Археологические исследования буддийского центра Каратепа в Старом Термезе Археологические исследования в Узбекистане-200о года. Самарканд. 2001. - С. 114-122. (In Russian).

46. Пидаев Ш.Р., Кюдзо К. Археологические работы на Каратепа в Старом Термезе // Археологические исследования в Узбекистане-2003 года. Тошкент. ЎзМЭ, 2004. Вып. 4. - С. 147-158. (In Russian).

47. Пидаев Ш.Р., Кюдзо К. О работах узбекистано-японской экспедиции на Кара-тепе в 1998 году // ОНУ. 1999. № 9-10. - С. 8284;

48. Пидаев Ш.Р., Кюдзо К. Термез. Токио, 2001. - 56 с. (In Japanese).

49. Пидаев Ш.Р., Лериш П. Археологические работы Узбекистано-Французской экспедиции на городище 
Старого Термеза в 2002 году // Археологические исследования в Узбекистане-2002 г. - Ташкент. Абдулла Қодирий номидаги Халқ меъроси нашриёти, 2003. №3. C. 134-143. (In Russian).

50. Пидаев Ш.Р., Лериш П., Папахристу О. Новые данные о раскопках в Старом Термезе // Археологические исследования в Узбекистане-200о г. - Самарканд. 2001. - C.105-114. (In Russian).

51. Пугаченкова Г. А., Тургунов Б.А. Буддийские святилище В загородной зоне // Дальверзинтепе-кушанский город на юге Узбекистана. Ташкент: Фан, 1978. - С. 90-97. (In Russian).

52. Пугаченкова Г.А. Новое в изучении Далварзинтепа // СА. M., 1971. №4, - C. 197. (In Russian).

53. Пугаченкова Г.А. Две ступы на юге Узбекистана // СА. - М., 1967. №3. - C. 257-263. (In Russian).

54. Ртвеладзе Э.В. К периодизации буддийского комплекса в Айртаме // ОНУ. 1995. № .5-8. - С. 72-77. (In Russian).

55. Соловьев В.С. Искусство раннесредневекового

Тохаристана. - Елец. 2007. - 129 c. (In Russian).

56. Ставиский Б. Я. Судьбы буддизма в Средней Азии. - М.: Наука, 1998. - 209 C. (In Russian).

57. Ставиский Б.Я. К предыстории археологического изучения Каратепе в Старом Термезе (работы летом 1936 года) // Краеведение Сурхандарьи. Ташкент, 1989. - С. 70-76. (In Russian).
58. Сталь-фон-Гольштейн А. СюаньДзань и результаты современных археологических исследований // ЗВОРАО. - СПб.: 1911. Т. ХХ. Вып. 1. - C. 9-22. (In Russian).

59. Стрелков А.С. Зурмала или Каттатюпе // Культура Востока. - М., Вып. І. 1927. - C. 27-30. (In Russian).

60. Strelkov A.S. Les Monument preislamique de Termez. Vol.3, \#4, - Zurich. "Artibus Asiae», 19281929. - Pp. 216-224. (In French).

61. Труды ТАКЭ / Отв. ред. Массон M.Е. - Ташкент. T. І. 1940. - 215 C. (In Russian).

62. Туды ТАКЭ / Отв. ред. Массон М.Е. - Ташкент. T. II. 1945. - 226 с. (In Russian).

63. Тургунов Б.А. Раскопки второго буддийского храма на Дальверзинтепе.

(Предварительное сообщения) // Античные и раннесредневековые древности Южного Узбекистана. - Ташкент: Фан, 1989. - С. 81-95. (In Russian).

64. Чориев 3., Аннаев Т., Муртазоев Б., Аннаев Ж. Ал-Хаким атТермизий. - Тошкент: Янги аср авлоди, 2008. - Б. 67-78. (In Uzbek). 